\title{
Evaluation of Business Process in the Cash Disbursement Cycle in Increasing Operational Effectiveness and Corporate Internal Control
}

\author{
(Case study: PT XYZ)
}

\author{
Rika Ramadiyansari \\ Master of Accounting, Economic and Business Faculty \\ Universitas Indonesia \\ Depok, Indonesia
}

\author{
Catur Sasongko* \\ Lecturer in Economic and Business Faculty \\ Universitas Indonesia \\ Depok, Indonesia \\ *rikaramadiyansari@gmail.com
}

\begin{abstract}
An industrial estate management company PT XYZ's actual situation based on internal audit report shows unusual activities and internal control related to the cash disbursement business process. The improvement process is needed in order to be able to run business process properly, avoid fraud, and present financial statements fairly. This research evaluates the effectiveness of current cash disbursement business process and its internal control using COSO 2013 framework. This research is a qualitative case study method that emphasizes the deepening of the analysis of a system, circumstances, events and interactions to answer the research problems. This study uses primary and secondary data obtained from interviews, observations and reviews of scientific and company documents. The result show company's weakness in running cash disbursement business process and its internal control. This research presents the evaluation of causes, weakness, risk identification and flowchart, which are correlated with internal controls to determine appropriate and effectiveness activity in cash disbursement business process.
\end{abstract}

Keywords—cash disbursement cycle, expenditure cycle, internal control, accounting information system

\section{INTRODUCTION}

Competition requires business to innovate and evaluate its business process to be more effective, efficient, and fraud avoidance. Lack of evaluation can reduce early detection of mismatches in functions and workflows which is impact on the lack of accuracy of information for decision making purpose. Information systems are a set of formal procedures where data is collected, processed into information, and distributed to users [1]. A report shows that the most common fraudulent occur in cash disbursement business process. It occurs when an employee uses his position of employment to cause payment for some inappropriate purpose [2]. Cash is the most liquid financial asset used for company operations and pays company's liability [3]. Cash is the only asset that is ready to be converted into other types of assets. Cash is very easy to hide, carry and most risky to fraudulent activities.

PT XYZ is an industrial estate management company whose main business is land leasing, buildings and other facilities/infrastructures [4]. The characteristics of cash disbursement transactions in PT XYZ are quite unique and material. Cash disbursement is intended to purchase services as part of the company's cost of sale, not to purchase raw materials or merchandise/inventory. PT XYZ's internal audit report shows that company hasn't applied cash disbursement business process and its internal control properly. It is proven by different cash opname, uncentralized cashier, past due payment, no vendor master data management, and no accrual payable. Opportunity, pressure, and rationality can lead someone to be fraudulent [5].

These findings indicate that the company requires a more adequate internal control in its cash disbursement cycle. Welldesigned internal control system can detect and avoid fraudulent [6]. Committee of Sponsoring Organizations of Treadway Commission (COSO) framework is one method which used in this research to evaluate the effectiveness of cash disbursement business process and its internal control by using five internal control components. The evaluations lead to the improvements of appropriate and effectiveness activity and its internal control in cash disbursement business process.

\section{A. Statement of Problem}

How is the current and improvement of cash disbursement cycle and its internal control at PT XYZ?

\section{B. Research Objective}

This research aims to evaluate business process and its internal control in the cash disbursement cycle at PT XYZ using the COSO 2013 framework. The evaluation results are 
used as a basis for proposals for cash disbursement cycle improvements and also as a reference for other researchers.

\section{LITERATURE REVIEW}

\section{A. Accounting Information System (AIS)}

It's a combination of people, hardware, software, communication networks, data sources, policies and procedures that are organized to store, display, transform, and disseminate information within an organization [7]. Information is a major part of maintaining a business. Business processes or transaction cycles are divided into 5 (five), namely the revenue cycle, the expenditure cycle, the production cycle, the personnel or payroll cycle, and the financial cycle [8]. Some of the benefits of AIS include improving quality and reducing cost of producing goods/services, sharing knowledge, increasing the efficiency and effectiveness of value chains, improving internal control structures and quality in decision making [1].

\section{B. Cash Disbursement Cycle}

The cash disbursement business process for company liability initially refers to the purchase order system created in the purchasing system. The main purpose of this system is to ensure that only valid creditors receive payments from the company and the value paid must be correct. The main control in the cash disbursement process is the use of a voucher system to support check withdrawals, the separation of payment approval functions and bank reconciliation [9]. The main activities of its cycle are ordering raw materials and/or equipment and/or inventory and/or work services to vendors, accepting orders sent or worked by vendors, reviewing and approving invoices from vendors and processing payments to vendor [8].

\section{Fraud Triangle Theory (FTT)}

Fraudulent caused by 3 (three) things: pressure, opportunity and rationality [10]. Pressure is a very dominant factor for individuals to commit fraud. Opportunity comes due to ineffective controls which enable individuals to commit fraud. Rationality explains that fraud man assume that their actions are acceptable.

\section{COSO 2013 Framework}

Basic objectives of internal control is to control the operational system and establish several levels of authority; to save company assets from loss, damage, inefficiency, theft, and fraud; to provide adequate, timely and reliable information
[11]. COSO 2013 framework with 5 components of the level of internal control as control environment, risk assessment, control activities, information and communication, and monitoring as variables to evaluate the internal control of cash disbursement cycle at PT XYZ [6].

\section{METHODS}

\section{A. Research Methodology}

This research is a qualitative case study approach. Case studies are used for research questions related to 'how' and 'why' [12]. This research began with an evaluation of the PT XYZ's cash disbursement business process and its internal control using the COSO 2013 framework.

\section{B. Types of Data}

Sources of data in this research are primary data and secondary data. In this research, primary data are obtained through interviews, discussions and observations while secondary data are from books, scientific journals, company documents, management reports, audit reports, financial reports, others.

\section{RESULTS AND DISCUSSION}

For current situation, the company has not used an integrated system in the business process of the cash disbursement cycle since the company was founded in 1973 until now. Every activity is carried out manually on a paperbased basis and need more time to produce report. Purchases have not been centralized and do not issue centralized Purchase Order (PO) and Working Order (WO). Not all purchases are received by the reception department. Vendor invoices are not directly received by account payable department. It makes the verification process slower and the payment process does not match with the due date of the invoice. Payment forms are numbered manually, there is no payable accrual and the purchase journal is on a cash basis.

The evaluation consists of 2 (two) parts, namely the stages of activities in the cash disbursement cycle and its internal control using COSO 2013 framework. Each stage explains its control objectives, facts, weakness factor, risks identification, COSO 2013 framework evaluation and proposed control activities to the cash disbursement business process improvement as explained Table 1, Table 2, Table 3, Table 4, Table 5, and Table6 below:

TABLE I. Process of PURChasing GoOdS/SERvices (StAGE A)

\begin{tabular}{|l|l|l|l|l|}
\hline No & \multicolumn{1}{|c|}{ Control Objectives } & \multicolumn{1}{|c|}{ Facts } & Weakness & \multicolumn{1}{c|}{ Risks } \\
\hline 1 & $\begin{array}{l}\text { Purchase Orders (PO) are placed only } \\
\text { for approved purchase requisitions (PR). }\end{array}$ & There is no PR issued. & Design & $\begin{array}{l}\text { 1. The company buys goods/services without needs analysis } \\
\text { 2. PO issuance is not in accordance with PR }\end{array}$ \\
\hline 2 & $\begin{array}{l}\text { Purchase orders (PO) are entered } \\
\text { accurately. }\end{array}$ & $\begin{array}{l}\text { Uncentralized PO issuance. } \\
\text { PO issuance is not } \\
\text { integrated with budget data. }\end{array}$ & $\begin{array}{l}\text { Design } \\
\text { 1. Purchase does not comply with specifications, poor quality, } \\
\text { low performance, and high prices }\end{array}$ \\
$\begin{array}{l}\text { 2. Return of poor goods/services } \\
\text { 3. Unproper endor selection process } \\
\text { 4. Fictitious vendors } \\
\text { 5. Bribes/Kickback } \\
\text { 6. Purchases exceed the budget limit }\end{array}$ \\
\hline
\end{tabular}


Table 1. Cont.

\begin{tabular}{|l|l|l|l|l|}
\hline 3 & $\begin{array}{l}\text { All purchase orders (PO) issued are } \\
\text { input and processed. }\end{array}$ & $\begin{array}{l}\text { There is no integrated } \\
\text { system and no specific and } \\
\text { prenumbered of PO. }\end{array}$ & Design & $\begin{array}{l}\text { 1. Manually reconcile documents } \\
\text { 2. Data is not update } \\
\text { 3. Receipt of goods/services does not represent PO issued } \\
\text { 4. Loss of monitoring PO status } \\
\text { 5. Do not have an audit trail }\end{array}$ \\
\hline
\end{tabular}

TABLE II. Process of Purchasing Goods/Services (Stage B)

\begin{tabular}{|c|c|c|}
\hline No & COSO 2013 Evaluation & Proposed Control Activity \\
\hline 1 & \multirow{3}{*}{$\begin{array}{l}\text { Control Environment; } \\
\text { Supervision still not refer to the cash } \\
\text { disbursement cycle } \\
\text { An authorization policy is inadequate } \\
\text { There is no specific training } \\
\text { Risk Assessment; } \\
\text { No specific risk identification and assessment } \\
\text { No risk fraud identification in PO issuance } \\
\text { activity. } \\
\text { Control Activities; } \\
\text { Control activities have not been developed } \\
\text { due to unclear risk identification. } \\
\text { Inefficiency Standard Operational Procedure } \\
\text { (SOP). } \\
\text { Information\&Communication; } \\
\text { Current SOP has socialized internally, but still } \\
\text { not perfect due to inefficient SOP. } \\
\text { Monitoring Activities; } \\
\text { PO monitoring still not done optimally since } \\
\text { there's no SOP and uncentralized PO } \\
\text { issuance. }\end{array}$} & $\begin{array}{l}\text { 1. Management must approve all purchase orders, with higher level management authority } \\
\text { required for unusual purchases (such as capital outlays or standing orders) and all } \\
\text { purchases that exceed established limits. Board approval is required for specified types of } \\
\text { purchases and this approval is appropriately documented. } \\
\text { 2. Purchase orders are reviewed and approved by management prior to mailing to the } \\
\text { supplier. } \\
\text { 3. Manage authorization lists with specific limits } \\
\text { 4. Restriction of access to authorization of PR and PO cancellation } \\
\text { 5. Vendor selection specifications to ensure goods/services come from registered vendors }\end{array}$ \\
\hline 2 & & $\begin{array}{l}\text { 1. Purchase order entry data is compared to source documents by independent individuals. } \\
\text { 2. Purchase orders are batched and batch input is balanced; out-of-balance batches are } \\
\text { corrected promptly. } \\
\text { 3. Purchase order data is edited and validated; identified errors are corrected promptly. }\end{array}$ \\
\hline 3 & & $\begin{array}{l}\text { 1. Purchase orders are sequentially prenumbered. The sequence of purchase orders processed } \\
\text { is accounted for. } \\
\text { 2. Purchase requisitioning, purchasing, inventory management, and accounts payable } \\
\text { functions are performed by an integrated application system. The general ledger is } \\
\text { automatically updated for receipt and disbursement transactions. }\end{array}$ \\
\hline
\end{tabular}

TABLE III. Account Payable Processing (Stage A)

\begin{tabular}{|c|c|c|c|c|}
\hline No & Control Objectives & Facts & Weakness & Risks \\
\hline 1 & $\begin{array}{l}\text { Amounts posted to accounts payable } \\
\text { represent goods and services received. }\end{array}$ & $\begin{array}{l}\text { PO and Receiving Report are } \\
\text { not submitted to payable } \\
\text { department in timely manner }\end{array}$ & Implementation & $\begin{array}{l}\text { 1. Long verification process } \\
\text { 2. Inappropriate recognition } \\
\text { 3. Missing documents }\end{array}$ \\
\hline 2 & $\begin{array}{l}\text { Accounts payable amounts are } \\
\text { accurately calculated and recorded in } \\
\text { the appropriate period. }\end{array}$ & $\begin{array}{l}\text { Payables are not recorded in } \\
\text { the appropriate period (but } \\
\text { are recorded on a cash basis) }\end{array}$ & Implementation & $\begin{array}{l}\text { 1. Payable General Ledger (GL) is not update } \\
\text { 2. GL does not represent received goods/services } \\
\text { 3. Note of the investments progress is not timely } \\
\text { manner } \\
\text { 4. Company cannot estimate expenditure budget } \\
\text { 5. Fictitious payment forms } \\
\text { 6. Have no purchase discount }\end{array}$ \\
\hline 3 & $\begin{array}{l}\text { All credit notes and adjustments to } \\
\text { account payable are only for valid } \\
\text { reasons, calculated accurately, recorded } \\
\text { in the appropriate period. }\end{array}$ & $\begin{array}{l}\text { Manual process and the } \\
\text { reference number is not } \\
\text { integrated }\end{array}$ & Design & $\begin{array}{l}\text { 1. Payable General Ledger (GL) is not update } \\
\text { 2. Do not have an audit trail for adjusting payable } \\
\text { accounts }\end{array}$ \\
\hline
\end{tabular}

TABle IV. Account Payable Processing (STAge B)

\begin{tabular}{|c|c|c|}
\hline No & COSO 2013 Evaluation & Proposed Control Activity \\
\hline 1 & \multirow{3}{*}{$\begin{array}{l}\text { Control Environment; } \\
\text { No commitment to record payable in timely } \\
\text { manner. } \\
\text { No detail procurement function in structure. } \\
\text { There is no specific training } \\
\text { Risk Assessment; } \\
\text { No risk identification for delay payable } \\
\text { recording } \\
\text { Control Activities; } \\
\text { Current SOP does not regulate of payable } \\
\text { recording } \\
\text { Information\&Communication; } \\
\text { No payment schedule information to supplier } \\
\text { Monitoring Activities: } \\
\text { Incomprehensive monitoring }\end{array}$} & $\begin{array}{l}\text { 1. Goods received are matched on-line or manually with purchase order details and/or invoices; long } \\
\text { outstanding goods receipt notes, purchase orders and/or invoices are investigated timely and } \\
\text { accrued as appropriate; documents are canceled once matched or on payment of the invoice to } \\
\text { prevent reuse. } \\
\text { 2. Invoices for goods/services received are authorized and accompanied by appropriate supporting } \\
\text { documentation. } \\
\text { 3. Management reviews recorded purchases } \\
\text { 4. Investigate the unmatched invoices }\end{array}$ \\
\hline 2 & & $\begin{array}{l}\text { 1. Goods/service receipt vouchers are prenumbered; the sequence of such vouchers is accounted for. } \\
\text { 2. Goods/service received, supplier invoices and credit notes received at, before, or after the end of } \\
\text { an accounting period are scrutinized and/or reconciled }\end{array}$ \\
\hline 3 & & $\begin{array}{l}\text { 1. Payable statement difference are investigated } \\
\text { 2. Management reviews and approves credit notes and adjustments prior to posting to accounts } \\
\text { payable. } \\
\text { 3. Access to credit note approval is restricted } \\
\text { 4. Management reviews all recorded nonsystematic debits }\end{array}$ \\
\hline
\end{tabular}


TABle V. C CAsh Disbursement Processing (Stage A)

\begin{tabular}{|c|c|c|c|c|}
\hline No & Control Objectives & Facts & Weakness & Risks \\
\hline 1 & $\begin{array}{l}\text { Disbursements are only } \\
\text { made for goods and } \\
\text { services received. }\end{array}$ & $\begin{array}{l}\text { Some payment made before } \\
\text { goods/service received }\end{array}$ & Design & $\begin{array}{l}\text { 1. Vendor does not send right } \\
\text { goods/services } \\
\text { 2. Fraudulent potentially } \\
\text { 3. Cash deficit }\end{array}$ \\
\hline 2 & $\begin{array}{l}\text { Disbursements } r \text { are } \\
\text { distributed to appropriate } \\
\text { supplier }\end{array}$ & $\begin{array}{l}\text { 1. No cashier control } \\
\text { 2. Past due Invoices } \\
\text { 3. Weak authorization }\end{array}$ & Design & $\begin{array}{l}\text { 1. Late payments } \\
\text { 2. Additional late fees } \\
\text { 3. Cash/Bank theft potentially }\end{array}$ \\
\hline 3 & $\begin{array}{lr}\text { Disbursements } & \text { are } \\
\text { accurately calculated and } \\
\text { recorded. }\end{array}$ & $\begin{array}{l}\text { 1. System is not integrated } \\
\text { 2. No cheque book } \\
\text { procedure }\end{array}$ & Design & $\begin{array}{l}\text { 1. Error calculation } \\
\text { 2. Fraudulent potentially }\end{array}$ \\
\hline 4 & $\begin{array}{l}\text { All disbursements are } \\
\text { recorded in the appropriate } \\
\text { time }\end{array}$ & $\begin{array}{l}\text { 1. Cash basis method } \\
\text { 2. No payment schedule }\end{array}$ & Design & $\begin{array}{l}\text { 1. Cash/Bank realization, GL of Account } \\
\text { Payable and budget data are not update } \\
\text { 2. No expenditure budget }\end{array}$ \\
\hline
\end{tabular}

TABLE VI. CAsh Disbursement Processing (Stage B)

\begin{tabular}{|c|c|c|}
\hline No & COSO 2013 Evaluation & $\begin{array}{l}\text { Proposed Control Activity } \\
\end{array}$ \\
\hline 1 & $\begin{array}{l}\text { Control Environment; } \\
\text { Comitment not fully implemented since } \\
\text { some payment done before goods/services } \\
\text { are received. } \\
\text { Cashier function is split to other division } \\
\text { without supervision from finance division. }\end{array}$ & $\begin{array}{l}\text { 1. Actual expenditures are compared to budget regularly; Reviews and } \\
\text { approves significant variances. } \\
\text { 2. Management reviews supporting documentation before approving payments. } \\
\text { 3. Documentation is canceled once payment is made. } \\
\text { 4. Review a listing of supplier payments prior to release. }\end{array}$ \\
\hline 2 & $\begin{array}{l}\text { Cashier hasn't got treasury training } \\
\text { Risk Assessment; }\end{array}$ & 1. Checks are restrictively endorsed by the preparer \\
\hline 3 & $\begin{array}{l}\text { There is no specific risk identification and } \\
\text { assessment for cash/bank expenditure } \\
\text { Control Activities; } \\
\text { Ineffective SOP } \\
\text { No payment schedule } \\
\text { Weak authorization } \\
\text { Information\&Communication; } \\
\text { An uncertain payment date }\end{array}$ & $\begin{array}{l}\text { 1. Payable statement difference are investigated } \\
\text { 2. Actual expenditures are compared to budget regularly; management reviews } \\
\text { and approves significant variances. } \\
\text { 3. Payment batch input data is balanced; identified errors are corrected } \\
\text { promptly. } \\
\text { 4. Disbursement input data is edited and validated; identified errors are } \\
\text { corrected promptly. }\end{array}$ \\
\hline 4 & $\begin{array}{l}\text { Cash position and budget information is not } \\
\text { real time } \\
\text { Monitoring Activities: } \\
\text { No spesific cash dibursement cycle } \\
\text { monitorting }\end{array}$ & $\begin{array}{l}\text { 1. Management reviews an aged accounts payable analysis and investigates any } \\
\text { unusual items. } \\
\text { 2. Bank statements are reconciled to general ledger. } \\
\text { 3. Checks are sequentially prenumbered; the sequence of checks processed is } \\
\text { accounted for. } \\
\text { 4. Disbursements at, before, after the end of an accounting period are } \\
\text { scrutinized to ensure complete and consistent recording in the appropriate } \\
\text { period. }\end{array}$ \\
\hline
\end{tabular}

The evaluation results show that PT XYZ's cash disbursement business process and its internal control is ineffective and inefficient. Cash disbursement flowchart describe below as a basis for policies and standard operational procedure. 


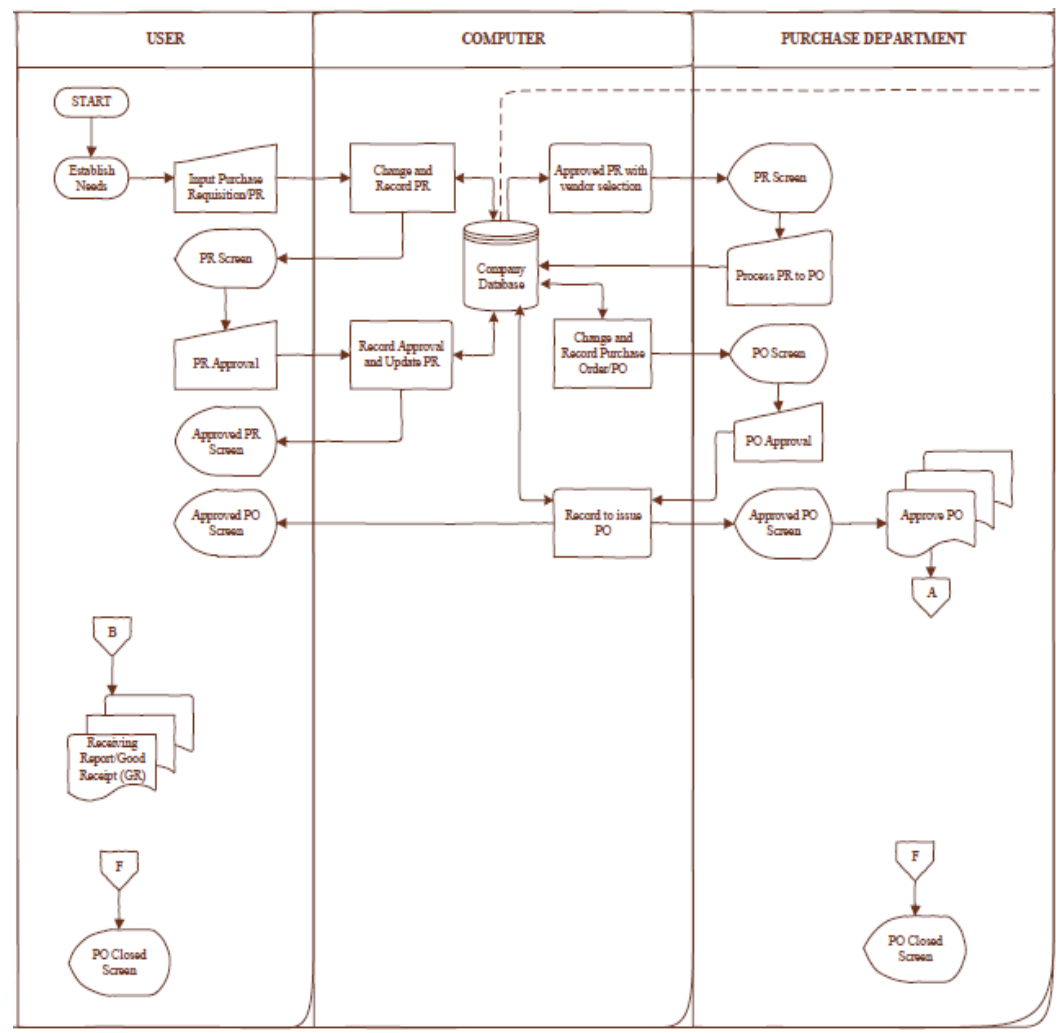

Fig. 1. Flow chart process of ordering goods/services.

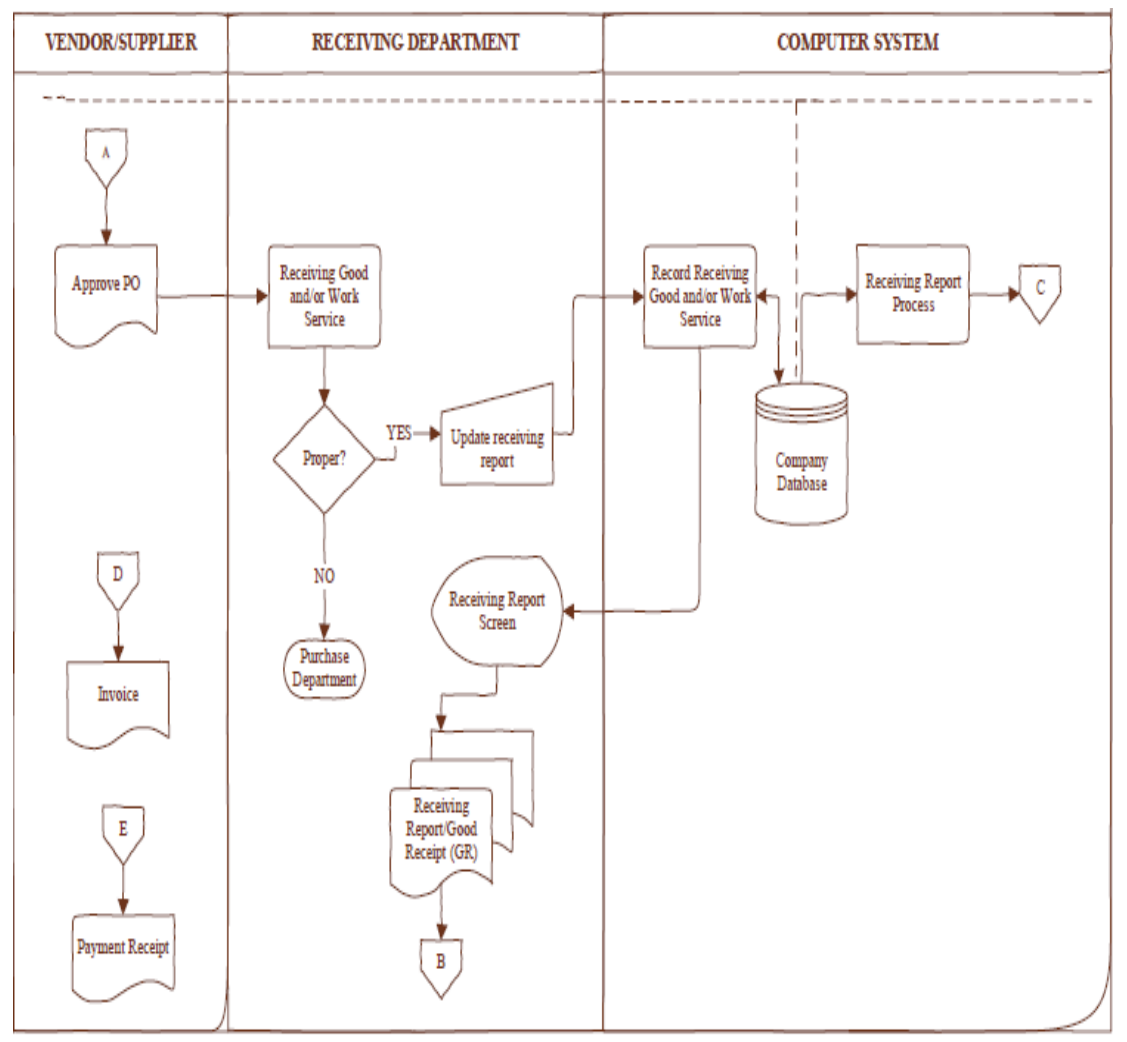

Fig. 2. Flow chart process of receiving goods/services. 
Figure 1 explains the process of ordering goods/services. The person in charge consist of user, computer system and purchase department. Purchasing activity starts from establish needs by issuing Purchase Requisition (PR). Computer system show PR number and approval request. Approved PR is forwarded to purchase department to issue Purchase Order (PO). Purchasing staff select registered vendor. The considerations are price, quality and vendor dependency level [8]. PO has information related to vendor name, delivery location, payment method, and orders [8]. Approved PO is sent to selected vendor.

Figure 2 explains the process of receiving goods/services. The person in charge consist of vendor, receiving department, and computer system. Receiving department make sure that goods/services delivered by vendor based on PO. If the delivery match with the PO and other supporting documents, then receiving department update the information to the computer system and produce receiving report.

Figure 3 explains the process of invoice verification, account payable record and payment process. The person in charge consist of account payable department, computer system, cashier, approval and general ledger. Vendor send invoice after the receiving report issued. Payable staff verify between PO, receiving report, tax invoice and other supporting documents. This activity calls " 3 way matching" concept. If all document confirmed, general ledger will be update by recording payable journal in appropriate time. Computer system show the payment date which based on invoice due date and purchase discount period. Payment voucher is prenumbered. General ledger will update the cash/bank and payable account while the cash/bank is debited. Computer system automatically update the PO status become "closed". This information will show in each related party's screen.

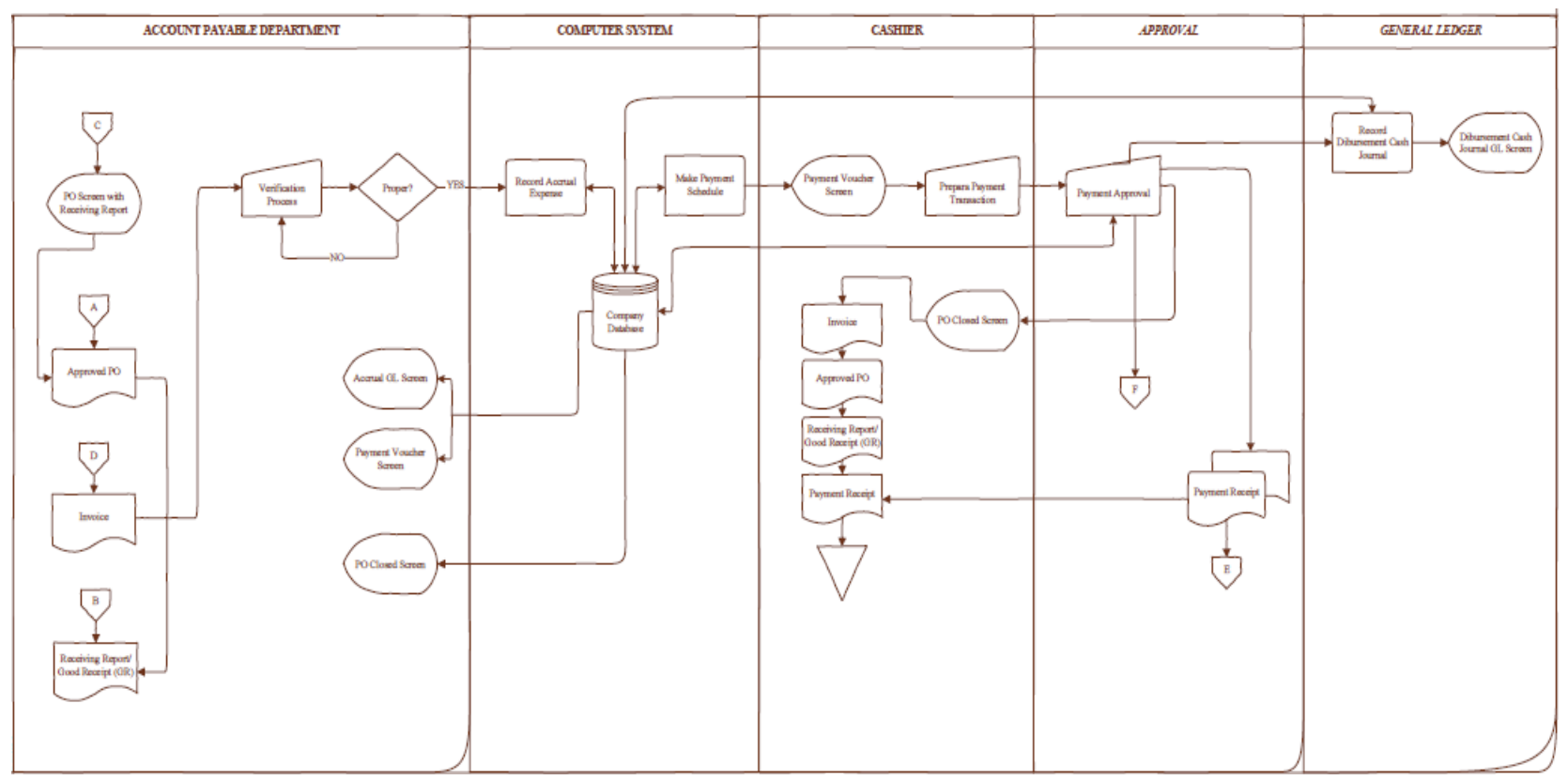

Fig. 3. Flow Chart Process of Invoice Verification, Account Payable Record, and Payment.

\section{CONCLUSION}

PT XYZ has several weaknesses in cash disbursement business process and its internal control such as inappropriate separation of functions, no purchasing system, no centralized Purchase Order and monitoring, no vendor master data, ineffective standard operational procedures (SOPs) and account payable recorded not in timely manner. Those weaknesses are possible impact to fraudulent. PT XYZ is supposed to review and its business process based on accounting information system along with internal control principal as explained above. The proposed flowchart can be use as reference to overcome its business process and internal control. Company is suggested to review policies and SOPs of cash disbursements business process which linked to Key Performance Indicator and Employee Discipline Regulations. Collaborate with vendors to have Enterprise Resource Planning (ERP) system. Future researchers are expected to develop application system design. Research Limitations are the evaluation tools based on accounting information system of cash disbursement business process and internal control by COSO 2013 framework. It doesn't compare with other similar company's.

\section{REFERENCES}

[1] J.A. Hall, Accounting Information Systems (7th Ed). USA: Cengage Learning. 2011.

[2] ACFE, Report to the Nations on Occupational Fraud and Abuse. Austinm, 2016.

[3] D. Martani, S. Veronica, R. Wardani, A. Farahmita amd E. Tanujaya, Akuntansi Keuangan Menengah Berbasis PSAK. Jakarta: Salemba Empat, 2012.

[4] Annual Report PT XYZ.

[5] T. Ruankaew, "Beyond the fraud diamond," International Journal of Business Management and Economic Research (IJBMER), vol. 7, no. 1, pp. 474-476, 2016. 
[6] J. Lutz, Committee of sponsoring organizations of the treadway commission: Internal control; integrated framework mit besonderer berücksichtigung der änderungen in der neuauflage 2013, 2015.

[7] J. O'Brien and G.M. Marakas, Introduction to Information Systems, McGraw-Hill/Irwin. New York, 2010.

[8] M.B. Romney and P.J. Steinbart, Accounting Information System (13th Ed). Essex: Person Education, Inc, 2015.
[9] G.H. Bodnar and W.S. Hopwood, Accounting Information Systems (11th Ed). New Jersey: Person Education, Inc. 2013.

[10] D.R. Cressy, Other People's Money. Montclair, NJ: Patterson Smith, 1953.

[11] A. Trenerry, Principles of Internal Control. New South Wales: New South Wales Press Ltd. 1999.

[12] R.K. Yin, Case Study Research: Design and Methods (3rd Ed),. 2003. 